\title{
Selection of patients with intractable epilepsy for resective surgery
}

Now that the technical problems of complex neurosurgical procedures are being daily minimised by advances in anaesthetic, surgical, and neurophysiological techniques, the key to the successful use of any procedure, or group of procedures, has become the selection of patients. The indications for considering operation in patients suffering from chronic epilepsy are not of course coincident with the criteria for selection for surgery, since the former are related to the patient's need for treatment and the latter to the likelihood of success. It is essential to make this distinction if the technical performance of the operative procedure is not the sole arbiter of success. Because these operations are uncommon, it is necessary to draw upon the experience gained with adults as well as children. The indications for considering surgery are disabling drug-resistant epilepsy, sufficiently well established not to resolve spontaneously, and occurring in the absence of severe mental retardation or serious psychiatric disease, with the exception of certain personality disorders. The radiological or neurophysiological findings are part of the selection process and will be discussed later. We are not concerned with the functional treatment of epilepsy-such as by stereotactic ablation of intracerebral targets or the use of chronic stimulating electrodes-mainly because at present there is no uniform agreement either about the procedures used or their results.

\section{Historical background}

It is useful to review briefly the way in which the surgery of epilepsy developed during the growth of neurosurgery. With the advent of asepsis, anaesthesia, and a knowledge of the principles of cerebral localisation, neurosurgery became a practical and serious subspeciality. Before the early part of the twentieth century, most reports of the surgical treatment of epilepsy described single cases, although there is a remarkable group of 5 patients surviving operation in 1828 by a Kentucky surgeon, Professor Dudley, with improvements in 3 of them. However, before the early part of this century most of the successful operations consisted of mere trepanation of the skull for the consequences of cerebral trauma; such operations were effective in patients in whom the epilepsy was due to the effects of various extracerebral collections. However, in about 1911 a number of papers began to appear describing the successful excision of post-traumatic cortical scars with the relief of epilepsy. A success rate of about $30 \%$ was reported for these procedures. A good account of the surgery of epilepsy for this period is given by Talairach et al. ${ }^{1}$

The scientific foundations of epilepsy surgery were laid by Foerster and Penfield ${ }^{2}$ after their successful experimental work on the maturation of cerebral scars showing that long-term changes included neovascularisation and distortion of cerebral structures. They transferred this knowledge to the treatment of patients with meningo-cortical scars as a consequence of head injury, demonstrating that clean excision of the scar reduced the epilepsy. Earl $^{3}$ had shown that electrical stimulation of the exposed cortex under local anaesthetic was useful in attempting to delineate the area to be excised in cases of focal epilepsy, especially if there was no obvious surface abnormality. This method was used too by Penfield in Montreal and as the number of cases operated on grew, it became evident that the results of excision were best when there was a discrete lesion to be demonstrated in the specimen. They also began to use the preoperative electroencephalogram (EEG) as an aid to prognosis ${ }^{4}$ and were able to say that if there was a focal abnormality in the EEG, the chances of a successful operation were about $67 \%$, but if there was no such abnormality, chances fell to $21 \%$. In this way the classical approach to resective surgery for epilepsy developed.

\section{Classical practice}

The classical approach is exemplified by the criteria suggested by Falconer and quoted by Jensen. ${ }^{5}$ Briefly, these are as follows. The patient should suffer with psychomotor seizures (that is focal epilepsy relevant to the area of proposed resection), which should be long-standing and resistant to treatment with drugs. The neuroradiological studies, which at that time did not include computerised tomography (CT) scans, should either be normal or show only slight atrophic changes affecting one 
temporal horn. The routine scalp EEG should consistently show a discharging spike focus in the anterior part of one temporal lobe. A sphenoidal recording should show a focus of spike discharges near the inferior aspect of the temporal lobe or over its infero-lateral aspect. Bilateral spike discharges were permissible if the frequency on the side of the proposed operation was at least 4 times that on the other side. The patient's full scale IQ should be at least 60 .

Using such criteria and provided the operative resection included the mesial temporal structures, it was possible to obtain good relief of the epilepsy and an amelioration of behavioural disorders with few hazards in a group of otherwise untreatable and poorly controlled epileptics. Such results have been obtained independently in a number of centres and are well summarised in a review article by Jensen. ${ }^{5}$ Some of these results are shown in Tables 1 and 2 . An analysis of the results of this type of surgery in 30 children was reported by Falconer and Davidson, ${ }^{6}$ and the results in 40 children (patients aged less than

Table 1 Results of anterior temporal lobectomy. ${ }^{5}$ (The figures indicate the percentage of patients in each series according to each outcome group).

\begin{tabular}{|c|c|c|c|c|c|c|}
\hline Cases & $\begin{array}{l}\text { Group } \\
I\end{array}$ & $\underset{2}{\text { Group }}$ & $\begin{array}{l}\text { Group } \\
3\end{array}$ & $\begin{array}{l}\text { Group } \\
4\end{array}$ & $\begin{array}{l}\text { Total } \\
\text { per- } \\
\text { centage } \\
\text { improved }\end{array}$ & $\begin{array}{l}\text { Operative } \\
\text { mortality }\end{array}$ \\
\hline Total (793) & $43 \cdot 6$ & 18 & $16 \cdot 5$ & $17 \cdot 3$ & $78 \cdot 1$ & $1 \cdot 1$ \\
\hline $\begin{array}{l}\text { GMNSU } \\
(103) \\
(101)\end{array}$ & $\begin{array}{l}37 \cdot 9 \\
41 \cdot 6\end{array}$ & $\begin{array}{l}13 \cdot 6 \\
19 \cdot 8\end{array}$ & $\begin{array}{l}29 \cdot 1 \\
21 \cdot 8\end{array}$ & $\begin{array}{l}16 \cdot 5 \\
15 \cdot 8\end{array}$ & $\begin{array}{l}81 \cdot 6 \\
83 \cdot 2\end{array}$ & $\begin{array}{l}1 \cdot 9 \\
0\end{array}$ \\
\hline $\begin{array}{l}\text { Paris (110) } \\
\quad \text { (La } \\
\text { Salpetriere) }\end{array}$ & $29 \cdot 1$ & $36 \cdot 2$ & $18 \cdot 1$ & $15 \cdot 5$ & $83 \cdot 5$ & $1 \cdot 0$ \\
\hline $\begin{array}{l}\text { Montreal } \\
(569)\end{array}$ & $43 \cdot 8$ & 21 & - & $35 \cdot 1$ & $64 \cdot 8$ & 0.2 \\
\hline
\end{tabular}

GMNSU $=$ Guy's-Maudsley Neurosurgical Unit.

Group 1 no seizures, group 2 seizure rate $75 \%$ improved, group 3 seizure rate $50 \%$ improved, group 4 seizure rate unchanged.

Table 2 Complications of anterior temporal lobectomy ${ }^{5}$

\begin{tabular}{|c|c|c|c|c|c|c|c|c|}
\hline & \multicolumn{2}{|c|}{$\begin{array}{l}G M N S U \\
(n=100)\end{array}$} & \multicolumn{2}{|c|}{$\begin{array}{l}\text { Paris } \\
(n=110)\end{array}$} & \multicolumn{2}{|c|}{$\begin{array}{l}\text { Montreal } \\
(n=161)\end{array}$} & \multicolumn{2}{|c|}{$\begin{array}{l}\text { Total } \\
(n=858)\end{array}$} \\
\hline & No & $(\%)$ & No & $(\%)$ & No & $(\%)$ & No & $(\%)$ \\
\hline $\begin{array}{c}\text { Hemiparesis } \\
\text { transient } \\
\text { permanent }\end{array}$ & $\begin{array}{l}6 \\
3\end{array}$ & $\begin{array}{l}(6) \\
(3)\end{array}$ & $\begin{array}{l}4 \\
2\end{array}$ & $\begin{array}{l}(3 \cdot 6) \\
(1 \cdot 8)\end{array}$ & $\begin{array}{l}4 \\
4\end{array}$ & $\begin{array}{l}(2 \cdot 5) \\
(2 \cdot 5)\end{array}$ & $\begin{array}{l}36 \\
21\end{array}$ & $\begin{array}{l}(4 \cdot 2) \\
(2 \cdot 5)\end{array}$ \\
\hline $\begin{array}{l}\text { Cranial nerve } \\
\text { palsy (3rd) } \\
\text { Dysphasia }\end{array}$ & $\begin{array}{l}15 \\
29\end{array}$ & $\begin{array}{l}(15) \\
(29)\end{array}$ & - & - & - & - & $\begin{array}{l}32 \\
45\end{array}$ & $\begin{array}{l}(3 \cdot 7) \\
(5 \cdot 2)\end{array}$ \\
\hline $\begin{array}{l}\text { Visual field de } \\
\text { Hemianopia } \\
\text { Quadrant- } \\
\text { anopia }\end{array}$ & $\begin{array}{r}\text { fect } \\
2\end{array}$ & $\begin{array}{c}==50) \\
(4)\end{array}$ & 66 & $(60)$ & 32 & (2) & 179 & $(15 \cdot 6)$ \\
\hline
\end{tabular}

GMNSU $=$ Guy's Maudsley Neurosurgical Unit.
Table 3 Results of temporal lobectomy in 40 children

\begin{tabular}{|c|c|c|c|c|}
\hline \multirow{2}{*}{$\begin{array}{l}\text { Pathological } \\
\text { findings }\end{array}$} & \multicolumn{2}{|c|}{ Worthwhile improvement } & \multicolumn{2}{|c|}{ Remainder } \\
\hline & Group I & Group 2 & Group 3 & Group 4 \\
\hline $\begin{array}{l}\text { Mesial } \\
\text { temporal } \\
\text { sclerosis }\end{array}$ & 14 & 6 & 4 & 0 \\
\hline Hamartoma & 5 & 2 & - & - \\
\hline $\begin{array}{l}\text { Tumour } \\
\text { Viral }\end{array}$ & 3 & 一 & - & 一 \\
\hline $\begin{array}{l}\text { encephalitis } \\
\text { Nonspecific }\end{array}$ & $\overline{1}$ & 二 & $\overline{1}$ & $\begin{array}{l}1 \\
5\end{array}$ \\
\hline
\end{tabular}

Group 1 fit-free or almost so, group 2 fit frequency $25 \%$ or less compared with preoperative rate, group 3 frequency $50 \%$ compared with preoperative rate, group 4 unchanged.

In 2 patients there was dual disease (Falconer, 1975, unpublished data).

15 years at operation), are shown in Table 3. The highest proportion of failures, as in adults, was in those patients in whom the resected temporal lobe contained no specific pathological lesion. It can be seen that the short-term results were good, but there are no long-term studies. It was hoped that the bad effects of chronic epilepsy on education and adolescence would be avoided. Unfortunately, in mixed and adult series the long-term results, especially if the epilepsy persists, are disappointing, the late mortality is high, although it is lower than in unoperated cases. ${ }^{7-8}$

Although in this annotation the emphasis is on temporal lobe resections, if similar considerations are applied to other parts of the cerebral hemispheres, especially if a clear lesion can be shown, results of a similar order can be obtained. Thus, although resections in the frontal, parietal, and central areas are less common, they can be equally successful. In this respect, an area of local and nonprogressive disease is the best situation for a good result; with rare exceptions, patients with progressive disease or only an electrical abnormality obtain either no benefit or only a transient improvement. Results of a large series of resections in cortical areas other than the temporal lobes were accumulated in Montreal and have been reviewed by Rasmussen. ${ }^{9}$

\section{Pathophysiology}

Epilepsy surgery has been well established in a number of centres now for at least 20 years, and it is useful to consider whether experimental knowledge and modern investigative techniques should alter these classical selection criteria. Otherwise we may be excluding from operation patients who might benefit.

The neurophysiological experiments relating to the surgery of epilepsy are those in which an irritative agent-such as penicillin powder, cobalt 
salts, or cold-are applied to the cortical surface so as to create a primary focus of epileptic activity. More recently even smaller foci have been created by the iontophoretic application of agents such as ferric salts. The epileptic activity at such a primary focus then gives rise to a secondary epileptic focus in the homotopic area of the contralateral cortex. At first this 'mirror' focus fires in relation to the primary focus and then becomes independent of it. The speed with which this process occurs varies, but generally speaking the higher the animal is on the evolutionary scale, the longer it takes and the less certain it is. Thus the time course ranges from a few hours in reptiles, through 12 hours to from 4 to 5 days in small laboratory mammals, to between 3 and 5 months in primates. Furthermore, if in these experiments the primary focus is ablated or disconnected by appropriate fibre tract section, then the 'mirror' focus may cease to be active.

It has proved impossible to demonstrate a similar sequence of events in the clinical situation, although one author has tried. ${ }^{10}$ There may be a number of reasons for this. Among them however, must be considered the idea that after a while the neurophysiological abnormalities become so bizarre and widespread that the patients automatically select themselves out of any consideration of surgery. However, sometimes the process is not progressive and a patient presents who has a single focus consistently proved over many years.

Goddard $^{\mathbf{1 1}}$ first described a process known as 'kindling' in which it was found that repetitive, twice daily, stimulation of certain parts of the rat's brain would lead to facilitation of epileptic pathways, and that this facilitation would persist after the stimulation had stopped. This phenomenon has no direct parallel in clinical experience, unlike the 'mirror' focus where there are certain analogous situations. It was pointed out by Krynauw, ${ }^{12}$ in his paper recommending hemispherectomy, that abnormalities in the healthy hemisphere in the EEG would recede and the appearance become more normal after the removal of the diseased hemisphere, and we have seen the same thing in isolated cases as did Falconer and Pond, who demonstrated in 2 patients that small, calcified lesions in the posterior temporal and parietal regions could give rise to anterior temporal abnormalities which resolved after removal of the lesion. Such a delayed improvement is fashionably known at the present time as 'run-down time'. ${ }^{13}$

Although the precise analogy with the 'mirror' focus cannot be demonstrated in patients, nevertheless, it can certainly be shown, using chronically implanted depth electrodes placed stereotactically, that although seizures may originate in one temporal lobe there may be more florid EEG abnormalities in the opposite one. Thus Crandall ${ }^{14}$ demonstrated that whereas, using scalp recording, a unilateral focus could only be demonstrated in $30 \%$ of their patients, the proportion could be increased to $73 \%$ by the use of this depth-recording technique.

\section{T scanning}

The relationship between EEG and structural abnormalities is clearly complex and has been further complicated by the introduction of CT scanning. In a population of chronic epileptics this investigation will increase the number of patients known to have organic lesions and in particular will increase the proportion in whom tumours are identified from 5 to $10 \% \cdot{ }^{15}$ Because this investigation will not show small atrophic lesions-such as mesial temporal sclerosis-a negative scan does not preclude surgery. However, CT scans will generally show tumorous lesions especially if iothalamate enhancement is used. The ability to see structural lesions more certainly with scanning has two important consequences in selecting patients for resective surgery. The first is that it resolves the situation if the EEGs show widespread abnormalities in the presence of a single structural lesion. In the past, with the aid of skilled and experienced neurophysiologists, together with certain additional manoeuvres such as the carotid amytal test, it has been possible to separate functional neurophysiological abnormalities from structural ones, but even so, the CT scan has made surgery possible in a group of patients who would earlier have been rejected. The second consequence is in relation to the age at which surgery is undertaken. Previously it was difficult to distinguish between those children in whom the epilepsy might settle down and those in whom it would persist, although patients who come to surgery in whom a clear lesion is found, it is a constant feature of the clinical history that the epilepsy has always been difficult to control with medication. The scanner helps to select some of these patients at an earlier stage. In addition, the demonstration of an abnormality on the CT scans, will often prompt the patient, his relatives, and the referring physician to enquire about surgery at an earlier stage in the illness.

\section{References}

1 Talairach J, Bancaud J, Szikla G, Bonis A, Geiers S, Vedronne C. Approche nouvelle de la neurochirugie de l'epilepsie. I. Introduction et historique. Neurochirurgie 1974: 20: Supplement 1, 5-24.

2 Foerster O, Penfield W. The structural basis of traumatic epilepsy and the results of radical operation. Brain 1930; 53: 99-119. 
3 Earl R. Surgical treatment of Jacksonian epilepsy. Minn Med 1919; 2: 325-9.

4 Jasper $\mathrm{H} \mathrm{H}$, Pertuiset B, Flanigin H. EEG and cortical electrograms in patients with temporal lobe seizures. Arch Neurol Psychiatry 1951; 65: 272-90.

5 Jensen I. Temporal lobe surgery around the world. Acta Neurol Scand 1975; 53: 354-73.

6 Falconer M A, Davidson S. The rationale of surgical treatment of temporal lobe epilepsy with particular reference to childhood and adolescence. In: Harris $\mathrm{P}$, Mawdsley C, eds. Epilepsy. Proceedings of the Hans Berger Centenary Symposium. Edinburgh: Churchill, Livingstone, 1974: 209-14.

7 Jensen I. Temporal lobe epilepsy-late mortality in patients treated with unilateral temporal lobe resections. Acta Neurol Scand 1975; 52: 374-80.

8 Taylor D C, Marsh S. Implications of long-term follow-up studies in epilepsy: with a note on the cause of death. In: Penry J K, ed. Epilepsy. The Eighth International Symposium. New York: Raven Press, 1977: 27-34.

9 Rasmussen T. Cortical resection for medically refractory focal epilepsy: results, lessons, questions. In: Rasmussen T, Marino R, eds. Functional neurosurgery. New York: Raven Press, 1979: 253-69.

10 Gupta P C, Dharampaul, Pathak S N, Singh B. Secondary epileptogenic EEG focus in temporal lobe epilepsy. Epilepsia 1973; 14: 423-6.

11 Goddard G V. Development of epileptic seizures through brain stimulation at low intensity. Nature 1967; 214: 1020-1.

12 Krynauw $R$ A. Infantile hemiplegia treated by removing one cerebral hemisphere. J Neurol Neurosurg Psychiatry 1950; 13: 243-67.

13 Falconer M A, Pond D A. Temporal lobe epilepsy with personality and behaviour disorders caused by an unusual calcifying lesion. J Neurol Neurosurg Psychiatry 1953; 16: 234-44.

14 Crandall $P$ H. Post-operative management and criteria for evaluation. In: Purpura D P, Penry J K, Ward R D, eds. Advances in neurology. Vol. 8. New York: Raven Press, 1975: 265-79.

15 Gastaut H, Gastaut J L. Computerised transverse axial tomography in epilepsy. Epilepsia $1976 ; 17: 325-36$.

C E Polkey

Neurosurgical Unit, Maudsley Hospital, De Crespigny Park, London SE5 8AZ 